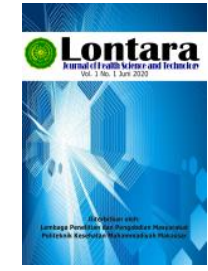

\author{
Lontara \\ Journal of Health Science and Technology \\ http://jurnal.poltekkesmu.online/lontarariset \\ Vol 1, No. 2, December 2020, pp 73-79 \\ p-ISSN:0000-0000 dan e-ISSN: 2721-6179 \\ DOI:https://doi.org/
}

\title{
Tatalaksana Pemeriksaan Thorax Pada Bayi Dengan Kasus Berat Badan Lahir Rendah (BBLR) Di Instalasi Radiologi RS Islam Faisal Makassar
}

\author{
Wahyuddin, AR.Rakhmansyah Iskandar, Nur Halisa Tul Ma'rifa \\ Radiologi, Politeknik Kesehatan Muhammadiyah Makassar \\ Email: wahyuddin@gmail.com
}

\begin{tabular}{l}
\hline \multicolumn{1}{c}{ Artikel info } \\
\hline \\
Artikel history: \\
Received;03-11-2020 \\
Revised:20-11-2020 \\
Accepted;07-12-2020 \\
\hline
\end{tabular}

Keyword:

Thorax, LBW, Infant.

Kata Kunci:

Thorax, BBLR, Bayi.

\begin{abstract}
L B W$ is one indicator to see how the degree or health status of children, so it plays an important role to monitor how the health status of children from birth. This study aims to find out how to administer Thorax Examination in Infants with a West Low Birth (BBLR) case at Faisal Makassar Islamic Hospital. In the research method, the writer uses qualitative research with a descriptive approach. From the results of the research conducted it can be concluded that the management of Thorax examination in infants with cases of Low Birth Weight $(L B W)$ in Faisal Islamic Hospital Makassar Antero Posterior projection (AP) is said to be enough to optimally diagnose the doctor's reading results namely bilateral pneumonia.
\end{abstract}

\begin{abstract}
Abstrak. BBLR merupakan salah satu indikator untuk melihat bagaimana derajat atau status kesehatan anak, sehingga berperan penting untuk memantau bagaimana status kesehatan anak sejak dilahirkan. Penelitian ini bertujuan untuk mengetahui bagaimana Tatalaksana Pemeriksaan Thorax pada Bayi dengan kasus Berat Badan Lahir Rendah (BBLR) di Rumah Sakit Islam Faisal Makassar. Pada metode penelitian, penulis menggunakan penelitian kualitatif dengan pendekatan deskriptif. Dari hasil penelitian yang dilakukan dapat disimpulkan bahwa tatalaksana pemeriksaan Thorax pada bayi dengan kasus Berat Badan Lahir Rendah (BBLR) di Rumah Sakit Islam Faisal Makassar proyeksi Antero Posterior (AP) dikatakan sudah cukup untuk menegakkan diagnose secara optimal dengan hasil baca dokter yaitu pneumonia bilateral.
\end{abstract}

Coresponden author:

Email: wahyuddin@gmail.com

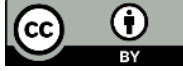

artikel dengan akses terbuka dibawah lisensi CC BY -4.0 


\section{PENDAHULUAN}

BBLR merupakan salah satu masalah kesehatan yang memerlukan perhatian di berbagai negara terutama pada negara berkembang atau negara dengan sosio-ekonomi rendah.

Bayi Berat Lahir Rendah ( BBLR) adalah bayi yang baru lahir dengan berat badan < 2500 gr. BBLR merupakan salah satu indikator untuk melihat bagaimana derajat atau status kesehatan anak, sehingga berperan penting untuk memantau bagaimana status kesehatan anak sejak dilahirkan, apakah anak tersebut status kesehatannya baik atau tidak (Putri et all, 2019).

Bayi dengan BBLR memiliki risiko lebih besar untuk mengalami gangguan pertumbuhan maupun perkembangan pada masa kanak-kanak. Anak dengan riwayat BBLR memiliki risiko mengalami gangguan pertumbuhan sampai dengan usia 2 tahun dan berisiko mengalami gangguan perkembangan pada 5 tahun pertama kehidupannya terutama jika tidak diimbangi dengan pemberian stimulasi yang lebih (Rosyidah and Mahmudiono, 2018).

BBLR disebabkan oleh kehamilan yang pendek (prematuritas), IUGR (Intra Uterine Restriction) yang dalam bahasa Indonesia disebut pertumbuhan janin terlambat (PJT) atau keduanya. Kedua penyebab ini dipengaruhi oleh faktor risiko, seperti faktor ibu, plasenta, janin dan lingkungan. Faktor risiko tersebut menyebabkan kurangnya pemenuhan nutrisi pada janin semasa kehamilan.

Berdasarkan data dari World Health Rankings tahun 2014 dari 172 negara di dunia, Indonesia menempati urutan ke 70 yang memiliki presentase kematian akibat BBLR tertinggi yaitu 10,69\% (Hartiningrum and Fitriyah, 2018). Tingkat kelahiran di Indonesia pada tahun 2010 sebesar 4.371.800 dengan kejadian BBLR sebesar 15,5 per 100 kelahiran hidup atau 675.700 kasus premature dalam 1 tahun.

BBLR dapat disebabkan oleh 2 hal yaitu kelahiran prematur atau kelahiran saat usia kehamilan < 37 minggu dan IUGR yang biasa disebut terganggunya pertumbuhan janin. BBLR dapat menyebabkan kesakitan bahakan kematian. Menetapkan penyebab BBLR antara perematur atau IUGR (Intra Uterina Growth Restriction) merupakan hal penting karena tingkat kematian antara kedua kondisi tersebut berbeda secara signifikan (Astria, et all., 2016).

Pemeriksaan radiologi Thorax merupakan pemeriksaan yang sangat penting. Kemajuan yang pesat selama dawarsa terakhir dalam teknik pemeriksaan radiologi Thorax dan pengetahuan untuk menilai suatu rontgen Thorax menyebabkan pemeriksaan Thorax dengan sinar-X menjadi suatu keharusan rutin. Suatu penyakit paru belum dapat disingkirkan dengan pasti sebelum dilakukan pemeriksaan radiologi. Hal ini menunjukkan betapa pentingnya pemeriksaan ini. Hal ini dikarenakan pemeriksaan ini relatif cepat, lebih murah dan mudah dilakukan pemeriksaan lain yang lebih canggih (Risnawati et.al., 2014).

Pediatric Radiografi adalah teknik radiografi yang digunakan pada usia 0-12 tahun (Apriliani, 2018) sehingga dalam kasus BBLR digunakan teknik pemeriksaan pediatric. Teknik pemeriksaan Thorax Bayi dengan kasus BBLR yang menggunakan tabung oksigen lebih baik dilepas, namun jika 
Tatalaksana Pemeriksaan Thorax Pada Bayi Dengan Kasus Berat Badan Lahir Rendah (BBLR) Di Instalasi Radiologi RS Islam Faisal Makassar

(Wahyuddin, AR.Rakhmansyah Iskandar, Nur Halisa Tul Ma'rifa)

keadaan tidak memungkinkan maka pastikan selang oksigennya tidak tumpang tindih dengan objek yang akan difoto.

Menurut Bontrager \& Lampignano (2013), Teknik Radiografi Pediatric pada pemeriksaan Thorax yang umum digunakan yaitu Antero Posterior (AP), Postero Anterior (PA), dan Lateral. Pediatric radiografi merupakan teknik pemeriksaan radiografi untuk anak usia 1 sampai 30 hari. Pemeriksaan ini berbeda jauh dengan pemeriksaan radiografi pada orang dewasa seperti persiapan pemeriksaan, alat fiksasi, faktor eksposi dan lain-lain.

Menurut Bontrager \& Lampignano (2013) pediatric adalah teknologi yang digunakan secara khusus untuk merawat dan memberikan diagnosa pada anak. Hal ini membutuhkan kesabaran, ketelitian untuk melakukan komunikasi dan menciptakan suasana yang bersahabat.

Dalam pemeriksaan Thorax pada bayi sangat membutuhkan ketelitian kesabaran dan teknik pemeriksaan khusus yang sedikit berbeda dengan pemeriksaan biasanya untuk menciptakan suasana yang bersahabat dan menghasilkan gambaran yang baik.

\section{BAHAN DAN METODE}

\section{A. Lokasi dan Rancangan Penelitian}

Jenis penelitian yang digunakan adalah penelitian kuantitatif deskriptif yaitu metode penelitian yang dilakukan dengan tujuan utama untuk membuat gambaran atau mendeskripsikan hasil penelitian berdasarkan data yang diperoleh dari lapangan kemudian menarik suatu kesimpulan. Penelitian dilakukan di instalasi radiologi Rumah Sakit Islam Faisal Makassar.

\section{B. Populasi dan Sampel}

Populasi yang digunakan dalam penelitian ini adalah semua pasien di Instalasi Radiologi dengan pengantar Berat Badan Lahir Rendah (BBLR) di Rumah Sakit Islam Faisal Makassar. Sampel yang diambil dalam penelitian ini adalah pasien dengan pengantar pemeriksaan Berat Badan Lahir Rendah (BBLR) di Rumah Sakit Islam Faisal Makassar.

\section{Teknik Pengambilan Sampel}

1. Observasi, dimana peneliti melakukan pengamatan dan dokumentasi pada Instalasi Radiologi Rumah Sakit Islam Faisal Makassaar.

2. Wawancara melakukan wawancara terhadap radiographer dan dokter spesialis radiologi yang berada di Instalasi Radiologi Rumah Sakit Islam Faisal Makassaar.

\section{Prosedur Penelitian}

\section{Alat dan Bahan}

Pada pemeriksaan Thorax bayi menggunakan pesawat konvensional dengan ukuran film 18 x $24 \mathrm{~cm}$. Beserta penanda marker R/L dengan menggunakan processing computer radiography.

2. Prosedur kerja

a. Menyiapkan alat 
b. Mengatur pesawat dan faktor eksposi

c. Mengatur pasien dan memposisikan objek

d. Processing film menggunakan CR.

\section{HASIL DAN PEMBAHASAN}

\section{A. Gambaran Umum Instalasi Radiologi RS Islam Faisal Makassar}

Bagian layanan radiologi RS Islam Faisal Makassar saat ini memiliki 3 orang Dokter spesialis radiologi dan 14 orang Radiografer. Berdasarkan kegiatan pelayanan radiologi setiap hari dibagi menjadi 3 sift, yaitu pagi, siang, malam. Adapun fasilitas dan sarana-sarana yang tersedia di bagian layanan radiologi saat ini dikategorikan sudah bisa untuk membantu menegakkan diagnosis antara lain sebagai berikut:

1) Mesin Automatic

2) Pesawat Konvensional

3) USG

4) CT Scan

5) Peralatan Support Diagnosa

\section{B. Deskripsi penelitian}

1. Identifikasi Pasien

$\begin{array}{ll}\text { Nama : By. M } \\ \text { Umur : 5 hari } \\ \text { Jenis Kelamin } & : \text { Perempuan } \\ \text { No. RM } & : 167454 \\ \text { No. Foto } & : 1776 \\ \text { Pemeriksaan } & : \text { Thorax } \\ \text { Diagnosa } & : \text { BBLR }\end{array}$

2. Persiapan Alat dan Bahan yang digunakan

a. Alat

1) Pesawat $X$-ray

Merk Tabung : Toshiba

Model : E7239

Daya Maksimum : 125 kV

Nomor Seri $\quad$ : 15F961

Tahun Pembuatan 2012

2) Film

Merk : Fuji Film

Ukuran : 24x30 Cm 
Jenis : Green Sensitif

3) Kaset

$$
\begin{aligned}
& \text { Merk : Agfa } \\
& \text { Type : cpg } 400 \\
& \text { Ukuran : } 24 \times 30 \mathrm{~cm} \\
& \text { Jenis IS : Green Sensitif }
\end{aligned}
$$
4) Marker : : R 1776
5) Processing : Automatic
6) Apron

\section{Teknik Pemeriksaan}

a. Tujuan Pemeriksaan

1) Untuk melihat abnormalitas congenital (jantung, vaskuler)

2) Untuk melihat adanya trauma (pneumothorax, haemothorax)

3) Untuk melihat adanya infeksi (umumnya tuberculosis/TB)

4) Untuk memeriksa keadaan jantung

5) Untuk memeriksa keadaan paru-paru

b. Indikasi pemeriksaa
1) Cardiomegaly
2) Tuberculosis
3) Effuse Pleura
4) Bronchitis

\section{c. Posisi Pasien}

Pasien baring di atas meja pemeriksaan, badan pasien menempel dengan kaset sejajar dengan garis tengah, dan kedua tangan pasien dipegang dengan keluarga pasien. Faktor eksposi yang digunakan di RS Islam Faisal Makassar yaitu $42 \mathrm{kV}$ dan 1,6 mAs.

d. Hasil Interpretasi Dokter
1) Pneumoni bilateral
2) Cor, sinus, dan diagfragma baik

\section{Pembahasan Penelitian}

Penelitian ini membahas tentang Tatalaksana pemeriksaan thorax pada bayi dengan kasus berat badan lahir rendah (BBLR) di RS Islam Faisal Makassar. Adapun teknik pemeriksaan diawali dengan persiapan pasien yaitu dengan melepas benda-benda penyebab artefak yang dapat mengganggu hasil radiograf kemudian dilanjutkan dengan memposisikan pasien.

Menurut Bontrager \& Lampignano (2013), pemeriksaan Thorax yang umum digunakan yaitu Antero Posterior (AP), Postero Anterior (PA), dan Lateral. Sedangkan teknik pemeriksaan yang 
dilakukan di RS Islam Faisal Makassar teknik pemeriksaan yang digunakan disesuaikan dengan permintaan dokter yaitu AP.

Berdasarkan hasil foto rontgen yang dilakukan, dilihat dari segi kualitas radiograf dari gambar yang sudah bagus, sehingga kesimpulan dokter radiologi berdasarkan hasil interpretasi menunjukkan pneumonia bilateral.

Penelitian tentang bayi dengan berat badan lahir rendah (BBLR) telah banyak dilakukan oleh peneliti sebelumnya, salah satunya adalah Roro dan Noviana (2018) dengan kasus yang sama dengan diagnosis yang berbeda, dimana hasil diagnosis yang diperoleh adalah Bronkopneumonia. Bronkopneumonia adalah peradangan parenkim paru yang melibatkan bronkus atau bronkiolus yang berupa distribusi berbentuk bercak-bercak.

\section{KESIMPULAN}

Berdasarkan hasil penelitian yang diperoleh bahwa tatalaksana teknik pemeriksaan thorax pada bayi berat badan lahir rendah (BBLR) di Instalasi Radiologi RS Islam Faisal Makassar hanya menggunakan proyeksi Antero Posterior (AP). Dari proyeksi tersebut sudah cukup memberikan hasil diagnose yaitu pneumoni bilateral, cor, sinus, dan diagfragma baik.

\section{DAFTAR PUSTAKA}

Aprilina, R., \& Nurhayati, A. Y. 2018. Efek Variasi Area Kolimasi Terhadap Dose Area Product (DAP) dan Kontras Radiograf Pada General Radiography (Doctoral dissertation).

Astria, Y., Suwita, C. S., Suwita, B. M., Widjaja, F. F., \& Rohsiswatmo, R. (2016). Low birth weight profiles at H. Boejasin Hospital, South Borneo, Indonesia in 2010-2012. Paediatrica Indonesiana, 56(3), 155-61.

Bontrager, K. L., \& Lampignano, J. (2013). Textbook of radiographic positioning and related Anatomy-E-Book. Elsevier Health Sciences.

Ekayuda, I. (2005). Radiologi Diagnostik. Jakarta: Balai Penerbit FKUI, 184-8.

Ellis, H. (2006). Applied Anatomy for students an Junior Doctors. Clinical Anatomy, 11, 119-121.

Hartiningrum, I., \& Fitriyah, N. (2018). Bayi Berat Lahir Rendah (BBLR) di Provinsi Jawa Timur Tahun 2012-2016. Jurnal Biometrika dan Kependudukan, 7(2), 97-104.

Lampignano, J., \& Kendrick, L. E. (2017). Bontrager's Textbook of Radiographic Positioning and Related Anatomy-E-Book. Elsevier Health Sciences.

Mahmudiono, T. (2018). Hubungan Riwayat BBLR Dengan Perkembangan Anak Prasekolah (Usia 45 Tahun) Di TK Dharma Wanita III Karangbesuki Malang. Amerta Nutrition, 2(1), 66-73.

Meschan, I. (1959). An atlas of normal radiographic anatomy. Academic Medicine, 34(10), 1055.

Muchtariadi, 2012. Dasar-Dasar Radiofarmasi: Pengembangan Untuk Diagnostik dan Terapi. Yogyakarta: Budi Utama 
Roro, R. W., \& Noviana, H. S. (2018). Bayi Usia 28 Hari dengan Bronkopneumonia. Jurnal Agromedicine, 5(2), 648-654.

Putri, A. W., Pratitis, A., Luthfiya, L., Wahyuni, S., \& Tarmali, A. (2019). Faktor Ibu terhadap Kejadian Bayi Berat Lahir Rendah. HIGEIA (Journal of Public Health Research and Development), 3(1), 55-62.

Risnawati, D., Ali, R. H., \& Tubagus, V. (2015). Gambaran Hasil Pemeriksaan Foto Toraks Pada Pasien Baru Yang Melakukan Pemeriksaan Toraks Foto Di Bagian/SMF Radiologi BLU RSUP Prof. Dr. Rd Kandou Manado Periode Juni-Oktober 2014. e-CliniC, 3(1).

Soeprijanto, B. (Ed.). (2017). Imejing Diagnostik pada Anomali Kongenital Sistem Traktus Urinarius. Airlangga University Press.

Udin, M. F. (2019). Buku Praktis Penyakit Respirasi pada Anak untuk Dokter Umum. Universitas Brawijaya Press.

Ulya, F. (2019). Teknik Pemeriksaan Radiografi Thorax Pediatrik Pada Kasus Bronchopneumonia Di Instalasi Radiologi RSUD Dr. R. Soedjati Soemadiardjo Purwodadi. 